\title{
Primary Intention Wound Healing and Esthetic Restoration in a Lacerated Lip Wound: The Hidden Drama, the Dynamics of Healing Process and Unanticipated Clinical Outcomes
}

\author{
Abhishek Singh Nayyar ${ }^{1 *}$, Vijaylakshmi KR ${ }^{2}$ and Mubeen Khan ${ }^{2}$ \\ ${ }^{1}$ Department of Oral Medicine and Radiology, Saraswati-Dhanwantari Dental College and Hospital and Post-Graduate \\ Research Institute, India \\ ${ }^{2}$ Department of Oral Medicine and Radiology, Government Dental College and Research Institute, India
}

*Corresponding author: Nayyar AS, Department of Oral Medicine and Radiology, Saraswati-Dhanwantari Dental College and Hospital and Post-Graduate Research Institute, Parbhani, Maharashtra, India, Tel: +91-98509 04067; E-mail: singhabhishekndls@gmail.com

Received: December 10, 2018; Accepted: December 27, 2018; Published: December 30, 2018

\section{Case Report}

This is a beautiful case of a patient who reported to the Outpatient Department with a deep-seated, lacerated wound on the lip apart from several minor abrasive injuries over the entire maxillo-facial region. The patient was conscious, well-oriented to time and place and very cooperative for clinical examination. On history elicitation, the patient gave a history of fall from a bike, a road transport accident (RTA) following which the patient along with the attendant rushed to the Centre for needful. On palpation, though the patient was found anxious and responded with pain, there was no clear-cut evidence found of any bony fracture in the maxillo-facial region although avulsion was noted in relation to tooth no.\#11 while Ellis class II fracture in relation to tooth no.\#21which was later, also, confirmed by the orthopantomograph (OPG) of the patient and other requisite views taken immediately after clinical examination of the patient including a para-nasal sinus view to check for evidence of any fractures in the concerned maxillo-facial region. The patient's lip was found to be badly lacerated (FIG. 1,2) for which healing by first intention was attempted by the vigorous cleaning of the wound area followed by induction of fresh bleeding and going for a clean, approximation of the lacerated tissues with support from external bandaging [1-5]. The patient was give injection of anti-tetanus serum (ATS) and was prescribed an antibiotic-anti-inflammatory coverage for 7 days. The patient was kept on a regular follow-up and for periodic revaluation of the healing lip wound (FIG. 3-9). Splinting was done to restrict mobility of the teeth in the anterior maxillary region followed by which an orthopantomograph (OPG) was taken (FIG.10,11). The results were found to be highly surprising on a meticulous follow-up of the patient. The healing was found to be uneventful and the patient's esthetics were, also, eventually, surprisingly, restored (FIG. 12,13). The need for any surgical procedure for the re-approximation of the lacerated wound, which has often been reported with an unesthetic

Citation: Nayyar AS, Vijaylakshmi KR, Khan M. Primary Intention Wound Healing and Esthetic Restoration in a Lacerated Lip Wound: The Hidden Drama, the Dynamics of Healing Process and Unanticipated Clinical Outcomes. Clin Case Rep Open Access. 2018;1(2):117.

(C)2018 Yumed Text. 
scarring and retraction of the lip tissues, was, thus, completely bypassed [6-11]. The patient was kept on follow-up for evaluation and further needful including the dental procedures required for the fractured tooth and the prosthetic rehabilitation of the avulsed tooth. The present case, thus, needs a mention in the literature and highlights the success of an attempt towards inducing healing by primary union (healing by first intention) in the lacerated facial tissues which can be used in other similar wounds, if required, and permitted by the situations under a strict, anti-infective environment and with maintenance of cleanliness in the wound apart from a meticulous follow-up and periodic re-evaluation of the patients [12-15]. The images presented have been acquired on follow-up of the patient on subsequent visits for reference.

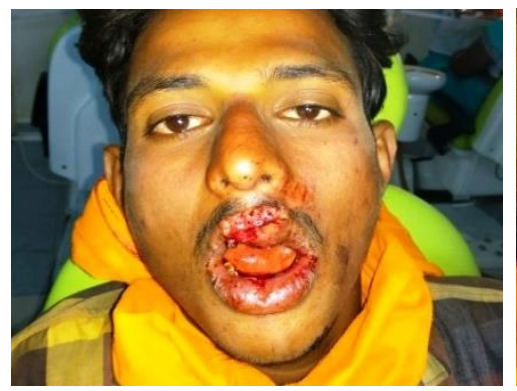

Fig. 1

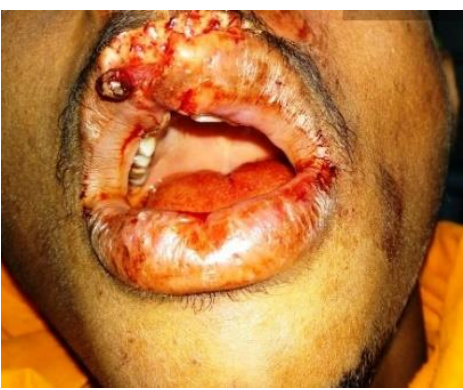

Fig. 2

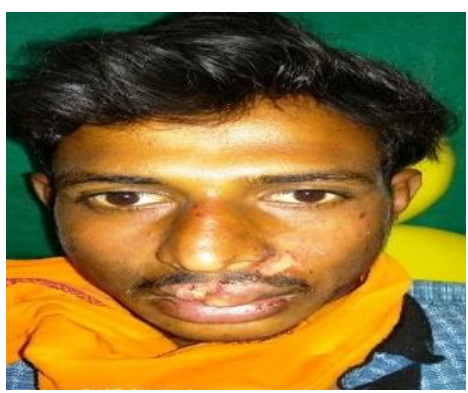

Fig. 3

FIG. 1. Immediate Post-trauma- Facial Profile View, FIG. 2. Immediate Post-trauma- Closer View and FIG. 3. 4-days Post-trauma- Facial Profile View.

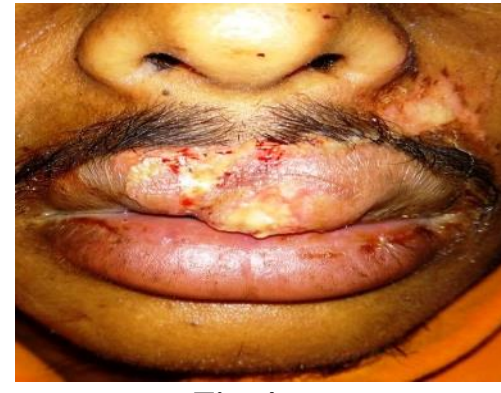

Fig. 4

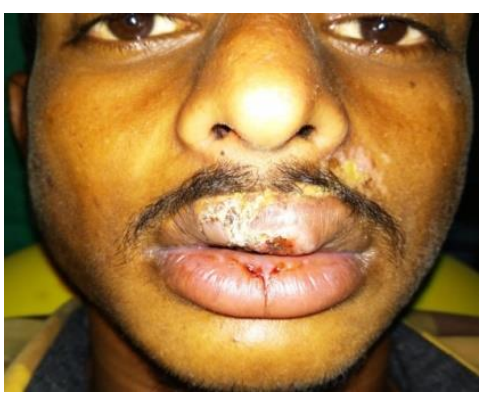

Fig. 5

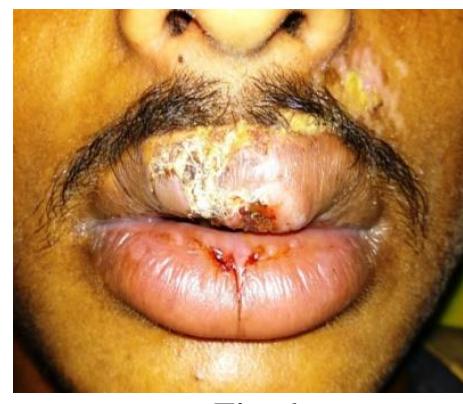

Fig. 6

FIG. 4. 4-days Post-trauma- Closer View, FIG. 5. 6-days Post-trauma- Facial Profile View and FIG. 6. 6-days Posttrauma- Closer View.

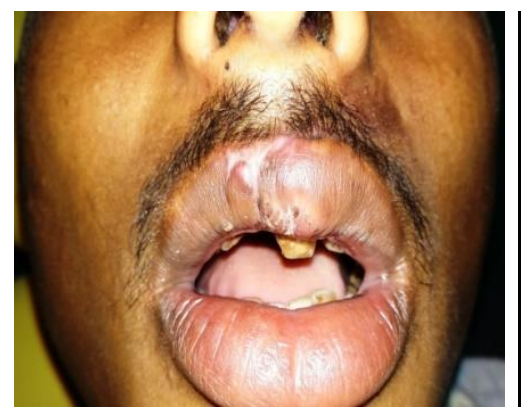

Fig. 7

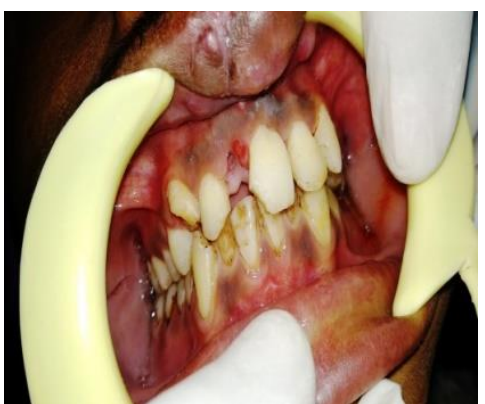

Fig. 8

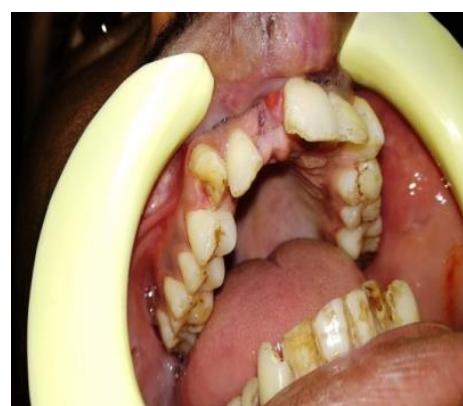

Fig. 9

FIG. 7. 68-days Post-trauma- Closer View, FIG. 8. 8-days Post-trauma Intra-oral Closed Mouth View with Teeth in Occlusion and FIG. 9. 8-days Post-trauma Intra-oral Open Mouth View. 


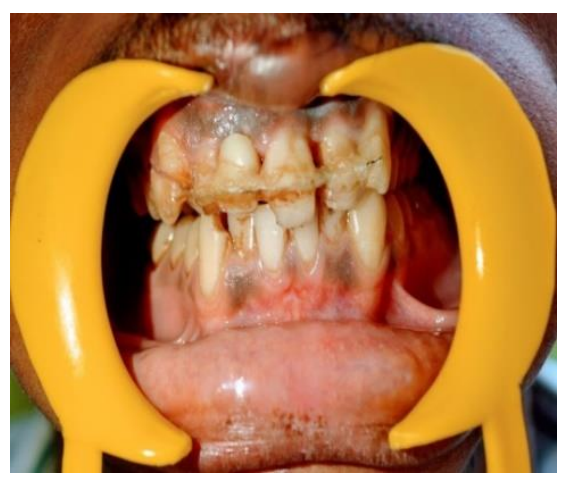

Fig. 10

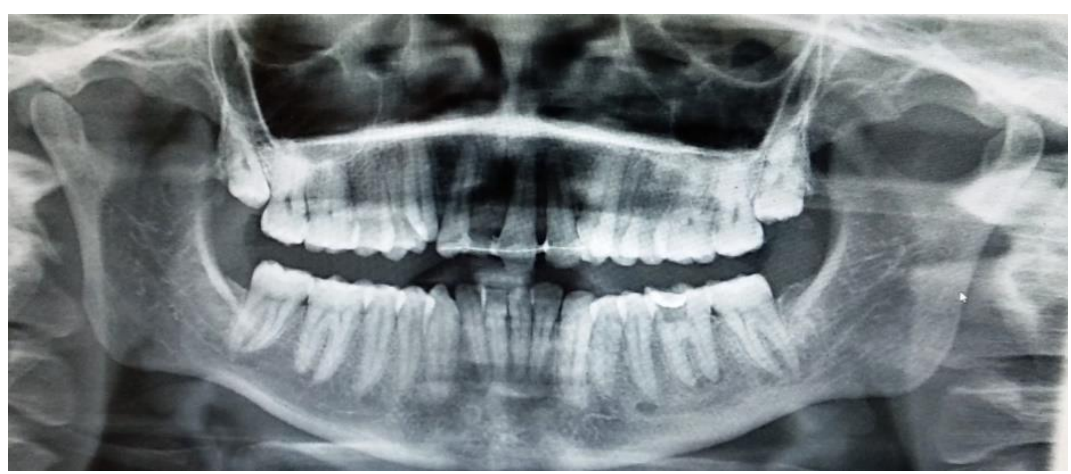

Fig. 11

FIG. 10. 3-weeks Post-trauma Intra-oral Closed Mouth View showing splinting done in anterior maxillary region, FIG. 11. Orthopantomograph of the patient 3-weeks Post-trauma revealing splinting done in the anterior maxillary region.

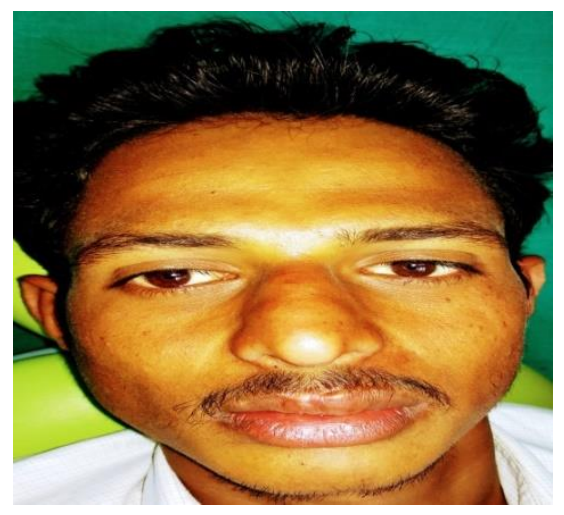

Fig. 12

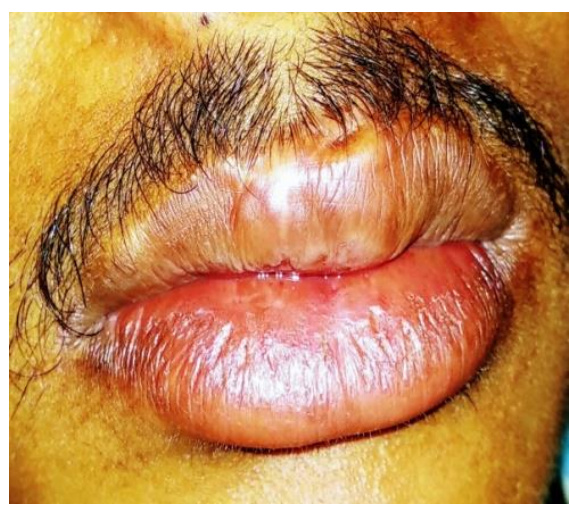

Fig. 13

FIG. 12. Facial Profile View at 4-weeks, FIG. 13. Closer View at 4-weeks.

\section{REFERENCES}

1. Lorentz HP, Longaker MT. Wounds: Biology, pathology and management. In: Norton JA, Barie PS, Bollinger RR, et al., editors. Surgery: Basic science and clinical evidence. 2nd ed. New York: Springer; 2008. 191-208 p.

2. Kumar V, Abbas AK, Fausto N, Aster JC. Tissue renewal, regeneration and repair. In: Robbins, Cotran, editors. Pathologic Basis of Disease. 8th ed. Philadelphia: Elsevier; 2010. 79-110 p.

3. Witte MB, Barbul A. General principles of wound healing. Surg Clin North Am. 1997;77(3):509-28.

4. Broughton G, Janis JE, Attinger CE. Wound healing: An overview. Plast Reconstr Surg. 2006;117(7):1-32.

5. Harper D, Young A, McNaught CE. The physiology of wound healing. Surg. 2014;32(9):445-50.

6. Werner S, Grose R. Regulation of wound healing by growth factors and cytokines. Physiol Rev. 2003;83(3):835-70.

7. Lawrence WT, Diegelmann RF. Growth factors in wound healing. Clin Dermatol. 1994;12:157-69.

8. Pierce GF, Mustoe TA, Altrock BW, et al. Role of platelet-derived growth factor in wound healing. J Cell Biochem. 2004;45(4):319-26. 
9. Pilcher BK, Wang M, Qin X, et al. Role of matrix metalloproteinases and their inhibition in cutaneous wound healing and allergic contact hypersensitivity. Ann NY Acad Sci. 2006;878:12-24.

10. Smola H, Thiekötter G, Fusenig NE. Mutual induction of growth factor gene expression by epidermal-dermal interaction. J Cell Biol. 1993;122(2):417-29.

11. Bluff J, Ferguson M, O'Kane S, et al. Bone marrow-derived endothelial progenitor cells do not contribute significantly to new vessels during incisional wound healing. Exp Hematol. 2007;35(3):500-6.

12. Diegelmann R. Analysis of collagen synthesis. Methods Mol Med. 2003;78:349-58.

13. Sandy-Hodgetts K, Carville K, Leslie GD. Determining risk factors for surgical wound dehiscence: A literature review. Int Wound J. 2015;12(3):265-75.

14. Robson MC. Wound infection: A failure of wound healing caused by an imbalance of bacteria. Surg Clin North Am. 1997;77(3):637-50.

15. Bucalo B, Eaglstein WH, Falanga V. Inhibition of cell proliferation by chronic wound fluid. Wound Rep Regen. 2002;1(3):181-6. 